\title{
Chemical fractionation and mobility of traffic-related elements in road environments
}

\author{
Ewa Adamiec
}

Received: 28 December 2016/ Accepted: 15 May 2017/Published online: 27 May 2017

(C) The Author(s) 2017. This article is an open access publication

\begin{abstract}
Due to considerable progress in exhaust control emission technology and extensive regulatory work regarding this issue, non-exhaust sources of air pollution have become a growing concern. This research involved studying three types of road environment samples such as road dust, sludge from storm drains and roadside soil collected from heavily congested and polluted cities in Poland (Krakow, Warszawa, Opole and Wroclaw). Particles below $20 \mu \mathrm{m}$ were examined since it was previously estimated that this fine fraction of road dust is polluted mostly by metals derived from non-exhaust sources of pollution such as brake linings wear. Chemical analysis of all samples was combined with a fractionation study using BCR protocol. It was concluded that the finest fractions of road environment samples were significantly contaminated with all of the investigated metals, in particular with $\mathrm{Zn}, \mathrm{Cu}$, both well-known key tracers of brake and tire wear. In Warszawa, the pollution index for $\mathrm{Zn}$ was on average 15-18 times the background value, in Krakow 12 times, in Wroclaw 8-12 times and in Opole 6-9 times the background value. The pollution index for $\mathrm{Cu}$ was on average 6-14 times the background in Warszawa, 7-8 times in Krakow, 4-6 times in Wroclaw and in Opole 5 times the background value. Fractionation study revealed
\end{abstract}

E. Adamiec ( $\square)$

AGH University of Science and Technology, 30 Mickiewicza Av., 30-059 Kraków, Poland e-mail: eadamiec@agh.edu.pl that mobility of examined metals decreases in that order: $\mathrm{Zn}(43-62 \%)>\mathrm{Cd}(25-42 \%)>\mathrm{Ni}(6-16 \%)>$ $\mathrm{Cu}(3-14 \%)>\mathrm{Pb}(1-8 \%)$. It should, however, be noted that metals even when not mobile in the environment can become a serious health concern when ingested or inhaled.

Keywords Brake lining · Non-exhaust emission · Oxidation stress $\cdot$ Heavy metals $\cdot$ BCR $\cdot$ Road dust

\section{Introduction}

Air pollution is regarded to be the biggest environmental risk factor responsible for premature deaths around the world (EEA 2016). As indicated by European Environmental Agency (EEA 2014), 64\% to even $92 \%$ of EU urban population is exposed to heavy loads of PM10 and PM2.5 particles. As a result, life expectancy of Europeans is reduced, on average, by about 8.6 months (WHO 2013) or even up to 22 months in the most polluted cities (Aphekom 2011). However, even despite ongoing fight for better air quality, the vast majority of population in urban areas is exposed to air which does not comply with any WHO Air Quality Guidelines.

Road vehicle emissions include exhaust and nonexhaust emissions, both strongly contributing to the overall air pollution problem. Extensive regulatory work regarding exhaust emission and technological 
improvements introduced by automobile industry have limited the percentage contribution of vehicle tailpipe emissions to total ambient PM concentrations (Gehrig et al. 2004; Thorpe and Harrison 2008; Mathissen et al. 2011; Pant and Harrison 2013), while non-exhaust particle emissions still remain high. As indicated by Dahl et al. (2006) and Kumar et al. (2013), even with zero tail pipe emissions, traffic will continue to contribute fine and ultra-fine particles through non-exhaust emissions. Moreover, Rexeis and Hausberger (2009) estimated that, by the end of the decade, nearly $90 \%$ of the total emissions from road traffic will come from non-exhaust sources. Since most studies on toxicity and health consequences of roadside PM are still focusing on diesel exhaust particles (DEPs), particles from the non-exhaust emission (sourced from wearable parts of vehicles) have not yet been so well recognized nor documented (van der Gon et al. 2013). Substantial amount of road dust could also be resuspended (50\% according to Garg et al. 2000; Bukowiecki et al. 2010; Kukutschová et al. 2011) and up to $50 \%$ of brake wear dust can enter the river system (Garg et al. 2000; Pratt and Lottermoser 2007; Bukowiecki et al. 2009). Moreover, health effects of non-exhaust emission particles are ignored at the regulatory level, despite their links with cardiopulmonary toxicity (Riediker et al. 2004a, b; Gottipolu et al. 2008; Gasser et al. 2009; Mantecca et al. 2009). Wear of brake pads is considered to be the primary source of non-exhaust emission, contributing to as much as 55 mass\% in PM10 emission (Harrison et al. 2012) or approximately $21 \%$ of the total emissions from road traffic (Bukowiecki et al. 2009; Gasser et al. 2009; Lawrence et al. 2013). Due to variety of materials used in the production of brake linings, the existing knowledge on the impact of new materials on both health and environment is not sufficient. Nowadays an exact amount of materials used in the braking systems is difficult to estimate; however, Chan and Stachowiak (2004) have described the most commonly used brake pad components. Since modern brakes are composed of various compounds, they differ significantly in chemical composition from the first-generation brake materials (Kukutschová et al. 2011). Table 1 contains the compilation of the most popular brake materials and additives used in brake systems.

As reported by many authors, e.g. Abu-Allaban et al. (2003), Tervahattu et al. (2006), Thorpe et al.
(2007), Kam et al. (2012), non-exhaust emissions contribute mainly to the coarse fraction of PM $(2.5-10 \mu \mathrm{m})$ and exhaust emissions contribute predominantly to fine PM of diameter $<2.5 \mu \mathrm{m}$. However, authors such as Vu et al. (2015), Grigoratos and Martini (2015) and Adamiec et al. (2016) report that fraction $<20 \mu \mathrm{m}$ is the best indicator of non-exhaust traffic emission, since $90 \%$ of all metals originated from brake pads belong to this particular fraction. The fine fraction of road dust $(<20 \mu \mathrm{m})$ should, therefore, be of special concern, since when inhaled or ingested under acidic $\mathrm{pH}$, it can cause a serious threat to human health and life. Kennedy and Hinds (2002) for instance conclude that particles of up to $100 \mu \mathrm{m}$ are inhalable (both via mouth and nose) and could lodge/deposit in the upper part of the respiratory tract. There are only scarce studies on transformation, mobility and speciation of non-exhaust traffic-related metals bound in the solid phase.

There is a considerable body of research on roadside soil (e.g. Carrero et al. 2013). For example, Werkenthin et al. (2014) present a very interesting survey of studies on metals in European roadside soils. Interestingly, there are fewer studies on road dust and only sporadic projects on sludge. Filgueiras et al. (2002) reviewed 400 extraction protocols for metal fractionation in environmental samples, and only 4 studies were conducted on road dust samples. Moreover, Świetlik et al. (2015) conclude that based on Scopus database of over 1500 abstracts and articles containing keyword "road dust" only approximately $5 \%$ of studies involved solid-phase speciation of heavy metals in road dust. Therefore, there is a substantial need for new studies on metal fractionation in road environments since it provides useful information on mobility and bioavailability of contaminants. Metals in road environments bound in various fractions such as carbonates, sulphides, organic matter, iron, aluminium and manganese oxyhydroxides as well as phyllosilicate minerals, and they undergo various processes such as ion exchange, sorption and/or adsorption as well as precipitation and/or co-precipitation. Bioavailability of heavy metals depends greatly on the characteristics of the particle surface or bond strength. Changes in chemical or physical conditions such as $\mathrm{pH}$, temperature, redox potential, organic matter decomposition, leaching, ion exchange processes and microbial activity in the environment all influence the release of toxic metals into environment. 
Table 1 Components of brake friction materials. Source: Eriksson et al. (1999), Gudmand-Hoyer et al. (1999), Eriksson and Jacobson (2000) and Chan and Stachowiak (2004)

\begin{tabular}{|c|c|}
\hline Function & Component and characteristics \\
\hline $\begin{array}{l}\text { Reinforcing } \\
\text { fibres }\end{array}$ & $\begin{array}{l}\text { Glass_-physically strong when bounded together with resinous binders, they exhibit thermal resilience } \\
\text { Metallic (steel, brass and copper)_in form of chips or granules, mixed with Zn minimizes corrosion; oxidized or } \\
\text { phosphatized fibres improve toughness and strength } \\
\text { Aramid - relatively soft, very light, excellent thermal stability, very good stiffness, superior wear resistance as } \\
\text { well as anti-fade properties compared to asbestos, because carcinogenic characteristics should not be considered } \\
\text { as asbestos replacement } \\
\text { Ceramic (potassium titanate) — thermally resilient, very hard, good wear resistance, high thermal stability but light } \\
\text { material } \\
\text { Sepiolite (hydrated magnesium silicate mineral)—excellent sorption properties, stable in high-temperature (even } \\
\text { above } 1000^{\circ} \mathrm{C} \text { ), because carcinogenic characteristics should not be considered as asbestos replacement }\end{array}$ \\
\hline Inorganic fillers & $\begin{array}{l}\text { Barium sulphate-increases density and wear resistance; stable at high temperature } \\
\text { Calcium carbonate - cheaper alternative to barium sulphate, but not stable at high temperatures. It imparts heat } \\
\text { stability to the friction material, thereby improving brake fade properties } \\
\text { Mica-suppresses low-frequency brake noise, causes interlayer splitting in friction material } \\
\text { Vermiculite - exfoliates rapidly into flakes at approximately } 800{ }^{\circ} \mathrm{C} \text {; suppress noises generated during braking } \\
\text { Alkali metal titanates (e.g. potassium and sodium titanates) - promotes stability of the friction coefficient } \\
\text { Molybdenum trioxide - prevents thermal fade and cracking of friction lining under high-temperature conditions }\end{array}$ \\
\hline Organic fillers & $\begin{array}{l}\text { Cashew dust and rubber-reduces brake noises due to its superior viscoelastic characteristics. Low thermal } \\
\text { conductivity prevents heat from transmitting to the backing plate of the brake friction material. Cashew particles } \\
\text { are also able to reduce fluctuations in friction coefficients, especially at elevated temperatures }\end{array}$ \\
\hline Binders & $\begin{array}{l}\text { Phenolic resin-cheap brake friction material acts as a matrix for binding together different substrates; brittle, low } \\
\text { impact resistance, highly toxic, decomposes at relatively low temperature, }\left(450{ }^{\circ} \mathrm{C}\right) \\
\text { Silicone-modified Phenolic resin-better impact resistance than pure phenolic resin; better heat and chemical } \\
\text { resistance than pure phenolic resin; enhanced water repellency } \\
\text { Epoxy-modified Phenolic resin-better heat resistance than pure phenolic resin. A pure epoxy resin is unable to } \\
\text { withstand high temperatures (above } 260{ }^{\circ} \mathrm{C} \text { ) } \\
\text { COPNA resin (condensed polynuclear aromatic resin) - its heat resistance is not significantly better than phenolic } \\
\text { resin as it decomposes at approximately the same temperature }\left(400-500{ }^{\circ} \mathrm{C} \text { ) }\right. \\
\text { Cyanate ester resins-high heat resistance, chemically inert, vibration dampener Brittle, low-impact resistance. } \\
\text { Brake pads with cyanate ester resins maintain their friction coefficients at elevated temperatures above } 350{ }^{\circ} \mathrm{C} \\
\text { and good adhesion } \\
\text { Thermoplastic polyamide resin-abrasion resistant; does not exhibit thermal fade, thermal conductivity three } \\
\text { times lower than phenolic resin }\end{array}$ \\
\hline & $\begin{array}{l}\text { Graphite - can be of natural or synthetic origin, in form of flakes or powder. In the flake form it improves } \\
\text { lubrication properties, while in powder form is able to dissipate heat generate during braking more effectively } \\
\text { Metal sulphides }\left(\mathrm{PbS}, \mathrm{SnS}_{2}, \mathrm{CuS}, \mathrm{Sb}_{2} \mathrm{~S}_{3}\right) \text { have good lubricating properties, with lower conductivities in } \\
\text { comparison to graphite. Toxicity of certain compounds such as lead and antimony sulphides is a disadvantage. } \\
\text { Therefore, relatively safer alternatives such as tin and copper sulphides would be ideal as lubricants } \\
\text { Aluminium oxide-hydrated form added as polishing and wear resistance agent. It is suitable as reinforcing fibres } \\
\text { used in brake pads and discs since it has high strength-weight ratio than metallic fibres } \\
\text { Magnetite }\left(\mathrm{Fe}_{3} \mathrm{O}_{4}\right) \text { improves cold friction and is a mild abrasive polishing component } \\
\text { Haematite }\left(\mathrm{Fe}_{2} \mathrm{O}_{3}\right) \text { is a mild abrasive polishing component } \\
\text { Zinc oxide }(\mathrm{ZnO}) \text { lubricates and polish drum } \\
\text { Chromium oxide }\left(\mathrm{Cr}_{2} \mathrm{O}_{3}\right) \text { raises friction } \\
\text { Lead oxide }(\mathrm{PbO}) \text { - friction modifier }\end{array}$ \\
\hline
\end{tabular}


Table 2 Sampling point location

\begin{tabular}{|c|c|c|c|}
\hline \multicolumn{4}{|c|}{ SAMPLING POINT LOCATION - GEOGRAPHICAL COORDINATES - NUMBER OF SAMPLES } \\
\hline & \multicolumn{2}{|c|}{ Sites near roads with heavy traffic and congestions } & \multirow{2}{*}{$\begin{array}{c}\text { Sites unpolluted with } \\
\text { traffic } \\
\text { Kościuszko Mound } \\
\left(50^{\circ} 03,245^{\prime} \mathrm{N} 19^{\circ} 53,467^{\prime} \mathrm{E}\right) \\
\text { Road dust } \mathrm{n}=3 \\
\text { Roadside soil } \mathrm{n}=3\end{array}$} \\
\hline $\begin{array}{l}3 \\
\frac{1}{2} \\
\frac{1}{2}\end{array}$ & $\begin{array}{c}\text { Av. Mickiewicza } \\
\text { Dębnicki Bridge } \\
\left(50^{\circ} 03,196^{\prime} \mathrm{N} 19^{\circ} 55,726^{\prime} \mathrm{E}\right) \\
\text { Road dust } \mathrm{n}=3 \\
\text { Sludge from drain storm } \mathrm{n}=3 \\
\text { Roadside soil } \mathrm{n}=3\end{array}$ & $\begin{array}{c}\text { Nowohucka St. } \\
\text { Nowohucki Bridge } \\
\left(50^{\circ} 03,306^{\prime} \mathrm{N} 19^{\circ} 59,810^{\prime} \mathrm{E}\right) \\
\text { Road dust } \mathrm{n}=3 \\
\text { Sludge from drain storm } \mathrm{n}=3 \\
\text { Roadside soil } \mathrm{n}=3\end{array}$ & \\
\hline 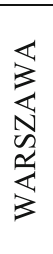 & $\begin{array}{c}\text { Av. Jerozolimskie } \\
\text { - ul. Poniatowskiego } \\
\text { Poniatowski Bridge } \\
\left(52^{\circ} 14,097^{\prime} \mathrm{N} 21^{\circ} 02,301^{\prime} \mathrm{E}\right) \\
\text { Road dust } \mathrm{n}=3 \\
\text { Sludge from drain storm } \mathrm{n}=3 \\
\text { Roadside soil } \mathrm{n}=3\end{array}$ & $\begin{array}{c}\text { ul. Słomińskiego } \\
\text { - ul Starzyńskiego } \\
\text { Gdański Bridge } \\
\left(52^{\circ} 15,589^{\prime} \mathrm{N} 21^{\circ} 00,456^{\prime} \mathrm{E}\right) \\
\text { Road dust } \mathrm{n}=3 \\
\text { Sludge from drain storm } \mathrm{n}=3 \\
\text { Roadside soil } \mathrm{n}=3\end{array}$ & $\begin{array}{c}\text { Fretta St. } \\
\left(52^{\circ} 15,099^{\prime} \mathrm{N} 21^{\circ} 00,484^{\prime} \mathrm{E}\right) \\
\text { Road dust } \mathrm{n}=3 \\
\text { Roadside soil } \mathrm{n}=3\end{array}$ \\
\hline $\begin{array}{l}\text { II } \\
0 \\
0 \\
0\end{array}$ & $\begin{array}{c}\text { ul. Niemodlińska } \\
\left(50^{\circ} 40,144^{\prime} \mathrm{N} 17^{\circ} 54,436^{\prime} \mathrm{E}\right) \\
\text { Road dust } \mathrm{n}=3 \\
\text { Sludge from drain storm } \mathrm{n}=3 \\
\text { Roadside soil } \mathrm{n}=3\end{array}$ & $\begin{array}{c}\text { ul. Nysy Łużyckiej } \\
\left(50^{\circ} 40,367^{\prime} \mathrm{N} 17^{\circ} 54,860^{\prime} \mathrm{E}\right) \\
\text { Road dust } \mathrm{n}=3 \\
\text { Sludge from drain storm } \mathrm{n}=3 \\
\text { Roadside soil } \mathrm{n}=3\end{array}$ & $\begin{array}{c}\text { Spacerowa Street } \\
\left(50^{\circ} 39,433^{\prime} \mathrm{N} 17^{\circ} 55,354^{\prime} \mathrm{E}\right) \\
\text { Road dust } \mathrm{n}=3 \\
\text { Roadside soil } \mathrm{n}=3\end{array}$ \\
\hline \begin{tabular}{l}
3 \\
\multirow{3}{3}{} \\
0 \\
0 \\
\multirow{2}{*}{} \\
3
\end{tabular} & $\begin{array}{c}\text { Al. Kromera - ul. Jedności } \\
\text { Narodowej } \\
\text { Gdański Bridge } \\
\left(51^{\circ} 07,770^{\prime} \mathrm{N} 17^{\circ} 03,441^{\prime} \mathrm{E}\right) \\
\text { Road dust } \mathrm{n}=3 \\
\text { Sludge from drain storm } \mathrm{n}=3 \\
\text { Roadside soil } \mathrm{n}=3\end{array}$ & $\begin{array}{c}\text { ul Nowaka-Jeziorańskiego } \\
\text { - ul. Milenijna } \\
\text { Milenijny Bridge } \\
\left(51^{\circ} 08,027^{\prime} \mathrm{N} 16^{\circ} 59,578^{\prime} \mathrm{E}\right) \\
\text { Road dust } \mathrm{n}=3 \\
\text { Sludge from drain storm } \mathrm{n}=3 \\
\text { Roadside soil } \mathrm{n}=3\end{array}$ & $\begin{array}{c}\text { Boulevard Kulczyńskiego } \\
\left(51^{\circ} 06,920^{\prime} \mathrm{N} 17^{\circ} 02,304^{\prime} \mathrm{E}\right) \\
\text { Road dust } \mathrm{n}=3 \\
\text { Roadside soil } \mathrm{n}=3\end{array}$ \\
\hline
\end{tabular}

Fractionation with the use of BCR protocol is a useful tool to distinguish between the anthropogenic and geochemical sources of metals in solid samples. It also provides essential information on the mobility and bioavailability of metals, transport mechanisms and, consequently, the impact those metals have on the environment and human health.

The aim of the study was to investigate various samples taken from road environment (such as road dust, sludge from storm drains and pavement dust), which are influenced mostly by non-exhaust emission and are located in close vicinity to urban roads in four biggest cities in Poland (Krakow, Warszawa, Wroclaw and Opole). Chemical analysis followed by the fractionation study using BCR protocol was conducted on the fraction $<20 \mu \mathrm{m}$ since this fraction has rarely been examined by researchers despite the fact that it should be regarded to be the best indicator of nonexhaust traffic emission.

\section{Materials and methods}

Sampling area

The sampling points (Table 2; Fig. 1) have been specifically selected to minimize the impact of other sources of contamination. Samples were collected in the period from May 2015 to December 2015 during summer and autumn sampling campaigns. Total of 148 samples from Krakow, Warszawa, Wroclaw and Opole were examined. Out of 12 sampling points, 8 are heavily affected by traffic and 4 are considered to be free of traffic influence. In each of those 12 research areas, samples of road sediment, sludge form storm drains and roadside topsoil (from $20 \mathrm{~cm}$ depth) were collected in summer and autumn sampling campaigns in 2015. Samples of road dust, including field duplicates, were collected in situ using a vacuum cleaner specifically modified for collecting road dust; some 


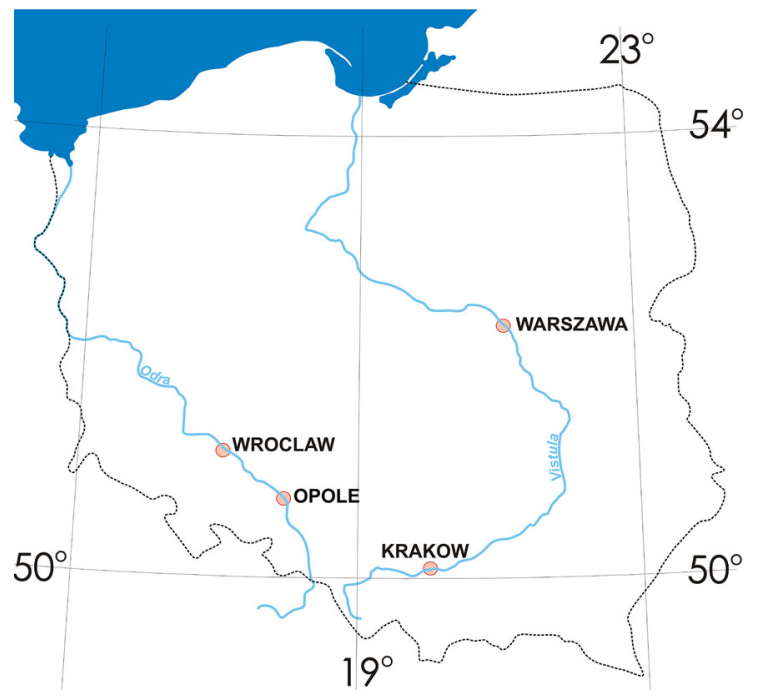

Fig. 1 Sampling areas

wet samples were swept with a brush from the road (rectangle $4 \mathrm{~m} \times 2 \mathrm{~m}$ ). Sludge was sampled from storm drains in the amounts of about $1000 \mathrm{mg}$. Roadside topsoil was collected from square sections of $1 \mathrm{~m} \times 1 \mathrm{~m}$, at $20 \mathrm{~cm}$ depth (about $10 \mathrm{~m}$ away from the bridge).

\section{Methods}

Metals were extracted from road dust, roadside topsoil and sludge from storm drains with aqua regia using microwave oven digestion protocol 3050B (EPA 1996). Fractionation study was conducted on 12 preselected samples according to BCR protocol (Ure et al. 1993). Table 3 presents reagents for sequential extraction procedure.

The concentrations of $\mathrm{Cd}, \mathrm{Cu}, \mathrm{Ni}, \mathrm{Pb}$ and $\mathrm{Zn}$ were analysed using inductively coupled plasma-mass spectroetry (ICP-MS) (ELAN 6100; PerkinElmer) according to US EPA method 6020A (EPA 1998). The concentrations of metals in road dust were then compared with the geochemical background based on Turekian and Wedephol (1961), since there are no geochemical background values determined for Polish soils in the fraction $<20 \mu \mathrm{m}$. World average shale values (ASV), considered to be the reference for the fraction of $20 \mu \mathrm{m}$, were as follows: for Cd $(0.3 \mathrm{mg} /$ $\mathrm{kg}), \mathrm{Cu}(45 \mathrm{mg} / \mathrm{kg}), \mathrm{Ni}(68 \mathrm{mg} / \mathrm{kg}), \mathrm{Pb}(20 \mathrm{mg} / \mathrm{kg})$ and $\mathrm{Zn}(95 \mathrm{mg} / \mathrm{kg})$. Furthermore, I geo index was calculated according to Müller (1969):

$I_{\text {geo }}=\log _{2} \cdot\left(\frac{C_{\mathrm{n}}}{1.5 \cdot B_{\mathrm{n}}}\right)$,

where $C_{\mathrm{n}}$ is the concentration of element $\mathbf{n}$ and $B_{\mathrm{n}}$ is the geochemical background.

\section{Data quality}

To obtain unambiguous and unbiased ICP-MS results, elements were also measured using inductively coupled plasma-optical emission spectroscopy (ICPOES) (OPTIMA 7300DV; PerkinElmer), atomic absorption spectroscopy (AAS) (F-AAS Thermo Scientific IC 3500) according to US EPA method 7000 in the Laboratory of Trace Analyses at the Faculty of Geology, Geophysics and Environmental Protection, AGH University of Science and Technology. To estimate the accuracies and biases of the analytical methods, reagent blanks and certified international reference materials BCR 701 (lake sediment), BCR 723 (road dust), ERM-CZ120 (fine dust PM $_{10}$-like) (EU JRC IRMM), METRANAL ${ }^{\mathrm{TM}} 32$ (light sandy soil, grain size $<100 \mu \mathrm{m}$ ) (Analytika Czech Republic) as well as SRM 1848a (urban particulate matter)

Table 3 Sequential extraction procedure according to BCR protocol

\begin{tabular}{llll}
\hline Step & Fraction & Targets phases & BCR protocol (Ure et al. 1993) \\
\hline 1 & $\begin{array}{l}\text { Exchangeable, water and } \\
\text { acid soluble }\end{array}$ & $\begin{array}{c}\text { Soluble species, carbonates, cation } \\
\text { exchangeable sites }\end{array}$ & $0.11 \mathrm{~mol} / \mathrm{L}$ acetic acid \\
2 & $\begin{array}{l}\text { Reducible } \\
\text { Fe and Mn oxyhydroxides }\end{array}$ & $\begin{array}{l}0.1 \mathrm{~mol} / \mathrm{L} \text { hydroxylammonium chloride, } \mathrm{pH} 2 \\
\text { Organic matter and sulphides }\end{array}$ & $\begin{array}{c}\text { Hydrogen peroxide followed by } 1.0 \mathrm{~mol} / \mathrm{L} \\
\text { ammonium acetate, } \mathrm{pH} 2\end{array}$ \\
$4^{\mathrm{a}}$ & Residual & Remaining, non-silicate bound metals & Aqua regia digestion
\end{tabular}

${ }^{\text {a }}$ The residual extraction step is not included in original procedure, but it can be useful for quality control, since sum of steps $1-4$ can be compared with digestion protocol 3050B (EPA 1996; Mossop and Davidson 2003) 
Table 4 Statistical parameters of road environmental samples

\begin{tabular}{|c|c|c|c|c|c|}
\hline Element (mg/kg) & $\mathrm{Cd}$ & $\mathrm{Cu}$ & $\mathrm{Pb}$ & $\mathrm{Ni}$ & $\mathrm{Zn}$ \\
\hline \multicolumn{6}{|l|}{ Kraków } \\
\hline \multicolumn{6}{|c|}{ Road dust $(n=6)$} \\
\hline Min-max & $1.65-2.56$ & $145-484$ & $98.7-285$ & $37.2-49.9$ & $600-1230$ \\
\hline Mean/median & $2.29 / 2.40$ & $363 / 384$ & $196 / 178$ & $44.0 / 43.9$ & $1043 / 1148$ \\
\hline \multicolumn{6}{|l|}{ Sludge $(n=6)$} \\
\hline Min-max & $2.85-3.28$ & $276-334$ & $177-213$ & $40.3-46.6$ & 1049-1302 \\
\hline Mean/median & $3.01 / 3.01$ & $305 / 308$ & $197 / 198$ & $43.7 / 44.3$ & $1177 / 1174$ \\
\hline \multicolumn{6}{|l|}{ Topsoil $(n=6)$} \\
\hline Min-max & $2.77-6.04$ & $89.0-189$ & $146 / 445$ & $39.3-61.4$ & $881-1844$ \\
\hline Mean/median & $3.83 / 3.96$ & $155 / 160$ & $218 / 185$ & $51.3 / 55.2$ & $1292 / 1255$ \\
\hline \multicolumn{6}{|l|}{ Warszawa } \\
\hline \multicolumn{6}{|c|}{ Road dust $(n=6)$} \\
\hline Min-max & $0.863-2.09$ & $136-1055$ & $214-258$ & $34.5-88.1$ & $651-2170$ \\
\hline Mean/median & $0.966 / 0.976$ & $606 / 649$ & $241 / 245$ & $64.8 / 72.2$ & $1426 / 1467$ \\
\hline \multicolumn{6}{|l|}{ Sludge $(n=6)$} \\
\hline Min-max & $1.03-6.42$ & $130-970$ & $145-363$ & $25.5-76.8$ & $799-4367$ \\
\hline Mean/median & $3.21 / 2.65$ & $580 / 612$ & $255 / 272$ & $58.9 / 63.5$ & $2214 / 1804$ \\
\hline \multicolumn{6}{|l|}{ Topsoil $(n=6)$} \\
\hline Min-max & $0.595-1.34$ & $188-331$ & $105-348$ & $37.9-45.4$ & $760-874$ \\
\hline Mean/median & $0.943 / 0.917$ & $262 / 264$ & $214 / 220$ & $42.9 / 42.3$ & $801 / 787$ \\
\hline \multicolumn{6}{|l|}{ Wrocław } \\
\hline \multicolumn{6}{|c|}{ Road dust $(n=6)$} \\
\hline $\operatorname{Min}-\max$ & $1.07-5.07$ & $70.0-295$ & $101-210$ & $55.8-284$ & $515-1851$ \\
\hline Mean/median & $1.97 / 1.58$ & $164 / 165$ & $161 / 163$ & $106 / 76.5$ & $1017 / 814$ \\
\hline \multicolumn{6}{|l|}{ Sludge $(n=6)$} \\
\hline Min-max & $1.24-3.42$ & $257-397$ & $182-301$ & $92.5-146$ & 819-2049 \\
\hline Mean/median & $2.25 / 2.16$ & $313 / 297$ & $230 / 219$ & $115 / 10$ & $1354 / 1275$ \\
\hline \multicolumn{6}{|l|}{ Topsoil $(n=6)$} \\
\hline $\operatorname{Min}-\max$ & $1.11-3.02$ & $61.0-84.5$ & $118-158$ & $46.7-56$ & $450-1131$ \\
\hline Mean/median & $2.02 / 1.98$ & $71.4 / 70.2$ & $135 / 132$ & $50.7 / 50.0$ & $772 / 754$ \\
\hline \multicolumn{6}{|l|}{ Opole } \\
\hline \multicolumn{6}{|c|}{ Road dust $(n=6)$} \\
\hline Min-max & $0.557-1.06$ & $114-312$ & $33.2-94.6$ & $107-299$ & $446-917$ \\
\hline Mean/median & $0.848 / 0.889$ & $212 / 210$ & $64.1 / 64.4$ & $203 / 203$ & $680 / 678$ \\
\hline \multicolumn{6}{|l|}{ Sludge $(n=6)$} \\
\hline $\operatorname{Min}-\max$ & $1.3-2.0$ & $129-817$ & $56.9-190$ & $109-567$ & $779-1757$ \\
\hline Mean/median & $1.48 / 1.35$ & $241 / 231$ & $96.2 / 75.4$ & $237 / 141$ & $1127 / 994$ \\
\hline \multicolumn{6}{|l|}{ Topsoil $(n=6)$} \\
\hline Min-max & $1.06-1.81$ & $58.2-106$ & $44.5-56.2$ & $61.1-340$ & $689-888$ \\
\hline Mean/median & $1.43 / 1.43$ & $81.9 / 82.1$ & $50.3 / 50.3$ & $201 / 202$ & $786 / 784$ \\
\hline
\end{tabular}

(NIST) were used to ensure that the obtained results met the required criteria. Analyses of the reference materials verified and confirmed the quality of the results. Analytical bias was statistically insignificant $(p=0.05)$, and the precisions of AAS and ICP-MS systems were satisfactory, which was verified by six 
Table 5 Statistical parameters of reference samples unpolluted with traffic

\begin{tabular}{|c|c|c|c|c|c|}
\hline Element $(\mathrm{mg} / \mathrm{kg})$ & $\mathrm{Cd}$ & $\mathrm{Cu}$ & $\mathrm{Pb}$ & $\mathrm{Ni}$ & $\mathrm{Zn}$ \\
\hline \multicolumn{6}{|l|}{ Kraków } \\
\hline \multicolumn{6}{|c|}{ Road dust $(n=3)$} \\
\hline Min-max & $0.679-0.988$ & $85.4-127$ & $67.5-98.2$ & $35.1-42.8$ & 209-371 \\
\hline Mean/median & $0.850 / 0.882$ & $106 / 107$ & $80.9 / 77.1$ & $39.4 / 40.2$ & $301 / 322$ \\
\hline \multicolumn{6}{|l|}{ Topsoil $(n=3)$} \\
\hline Min-max & $0.477-0.804$ & $79.0-122$ & $54.3-89.3$ & $32.3-44.4$ & $162-289$ \\
\hline Mean/median & $0.616 / 0.568$ & $102 / 102$ & $70.1 / 76.6$ & $38.7 / 39.3$ & $218 / 202$ \\
\hline \multicolumn{6}{|l|}{ Warszawa } \\
\hline \multicolumn{6}{|c|}{ Road dust $(n=3)$} \\
\hline Min-max & $0.675-1.09$ & $88.1-148$ & $98.3-168$ & $29.5-45.4$ & $161-370$ \\
\hline Mean/median & $0.880 / 0.876$ & $113 / 102$ & $136 / 143$ & $36.5 / 34.5$ & $278 / 302$ \\
\hline \multicolumn{6}{|l|}{ Topsoil $(n=3)$} \\
\hline Min-max & $0.395-0.665$ & $67.5-110$ & $87.3-112$ & $28.8-50.3$ & $107-274$ \\
\hline Mean/median & $0.574 / 0.663$ & $88.3 / 87.4$ & $99.2 / 98.2$ & $37.8 / 34.4$ & 193/198 \\
\hline \multicolumn{6}{|l|}{ Wrocław } \\
\hline \multicolumn{6}{|c|}{ Road dust $(n=3)$} \\
\hline Min-max & $0.707-1.77$ & $54.3-69.8$ & $87.4-116$ & $54.0-87.6$ & $167-334$ \\
\hline Mean/median & $1.25 / 1.27$ & $60.1 / 56.3$ & $101 / 101$ & $76.2 / 87.0$ & $241 / 221$ \\
\hline \multicolumn{6}{|l|}{ Topsoil $(n=3)$} \\
\hline Min-max & $0.591-1.21$ & $39.2-56.8$ & $76.2-108$ & $43.7-49.3$ & 146-309 \\
\hline Mean/median & $0.930 / 0.988$ & $50.1-54.2$ & $90.5 / 87.3$ & $46.1 / 45.3$ & $218 / 198$ \\
\hline \multicolumn{6}{|l|}{ Opole } \\
\hline \multicolumn{6}{|c|}{ Road dust $(n=3)$} \\
\hline Min-max & $0.321-0.744$ & $45.5-87.1$ & $54.2-68.6$ & $59.3-93.4$ & $132-290$ \\
\hline Mean/median & $0.654 / 0.744$ & $66.2 / 65.9$ & $60.5 / 58.8$ & $76.3 / 76.3$ & $208 / 202$ \\
\hline \multicolumn{6}{|l|}{ Topsoil $(n=3)$} \\
\hline Min-max & $0.381-1.01$ & $34.4-65.9$ & $38.4-54.2$ & $45.4-102$ & 119-276 \\
\hline Mean/median & $0.759 / 0.886$ & $47.9 / 43.5$ & $46.0 / 45.5$ & 75.2/78.1 & $192 / 180$ \\
\hline
\end{tabular}

different solution injections. Rh was used as an internal standard. Using ICP-MS, element correction equations were used for each element to minimize the impact of interferences.

\section{Results and discussion}

Concentrations of $\mathrm{Cu}$ and $\mathrm{Zn}$, the well-known key tracers of non-exhaust brake and tire wear, were highly elevated in fine fractions of all types of road environment samples in the examined cities. In Warszawa, the pollution index (Chen et al. 2005; Radziemska and Fronczyk 2015) calculated for $\mathrm{Zn}$ was on average 15-18 times the background value, in Krakow 12 times, in Wroclaw 8-12 times and in Opole 6-9 times the background value. Furthermore, the pollution index for $\mathrm{Cu}$ was found to be on average 6-14 times the background value in Warszawa road environment, 7-8 times in Krakow, 4-6 times in Wroclaw and 5 times the background value in Opole. Road dust and sludge from storm drains were the most contaminated of all road environment samples in each of the cities; however, Krakow and Warszawa were especially contaminated with $\mathrm{Cu}$ and $\mathrm{Zn}$ due to heavy traffic congestions as well as poor infrastructure.

The highest concentrations of $\mathrm{Cd}$ in all road environment samples were found in Krakow and Wroclaw. Similar results were obtained for the concentration of $\mathrm{Pb}$, which was the highest in sludge 
Cd

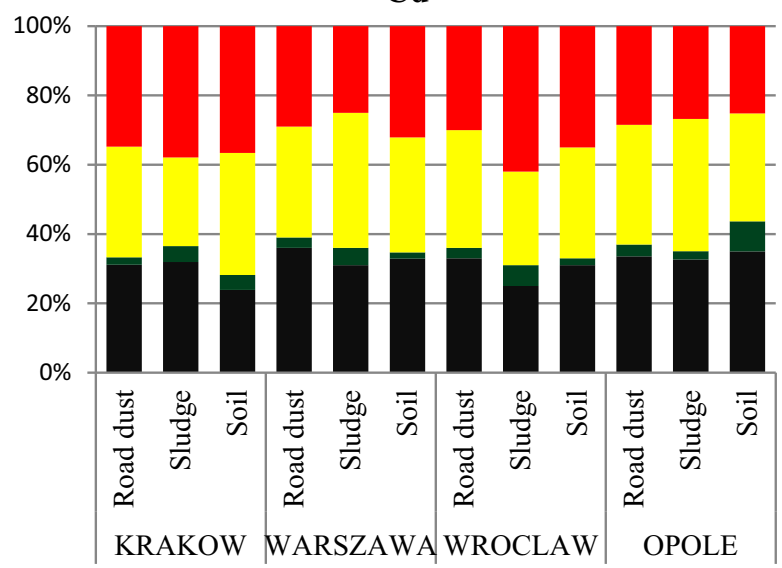

Cu

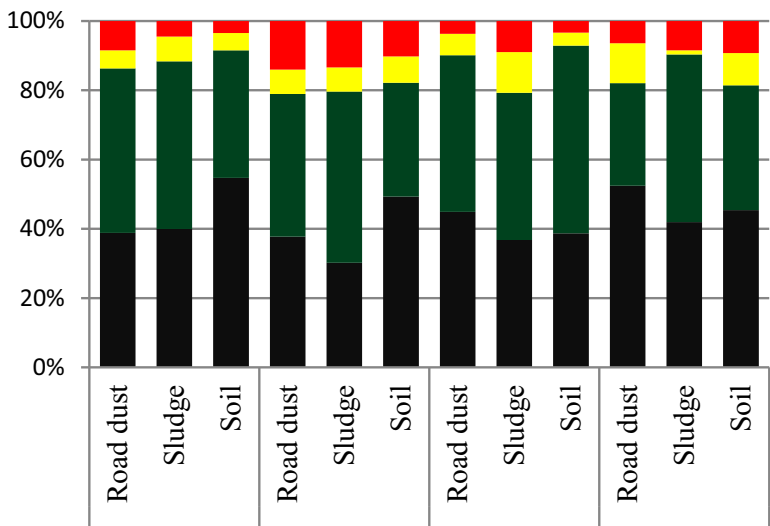

KRAKOW WARSZAWA WROCLAW OPOLE
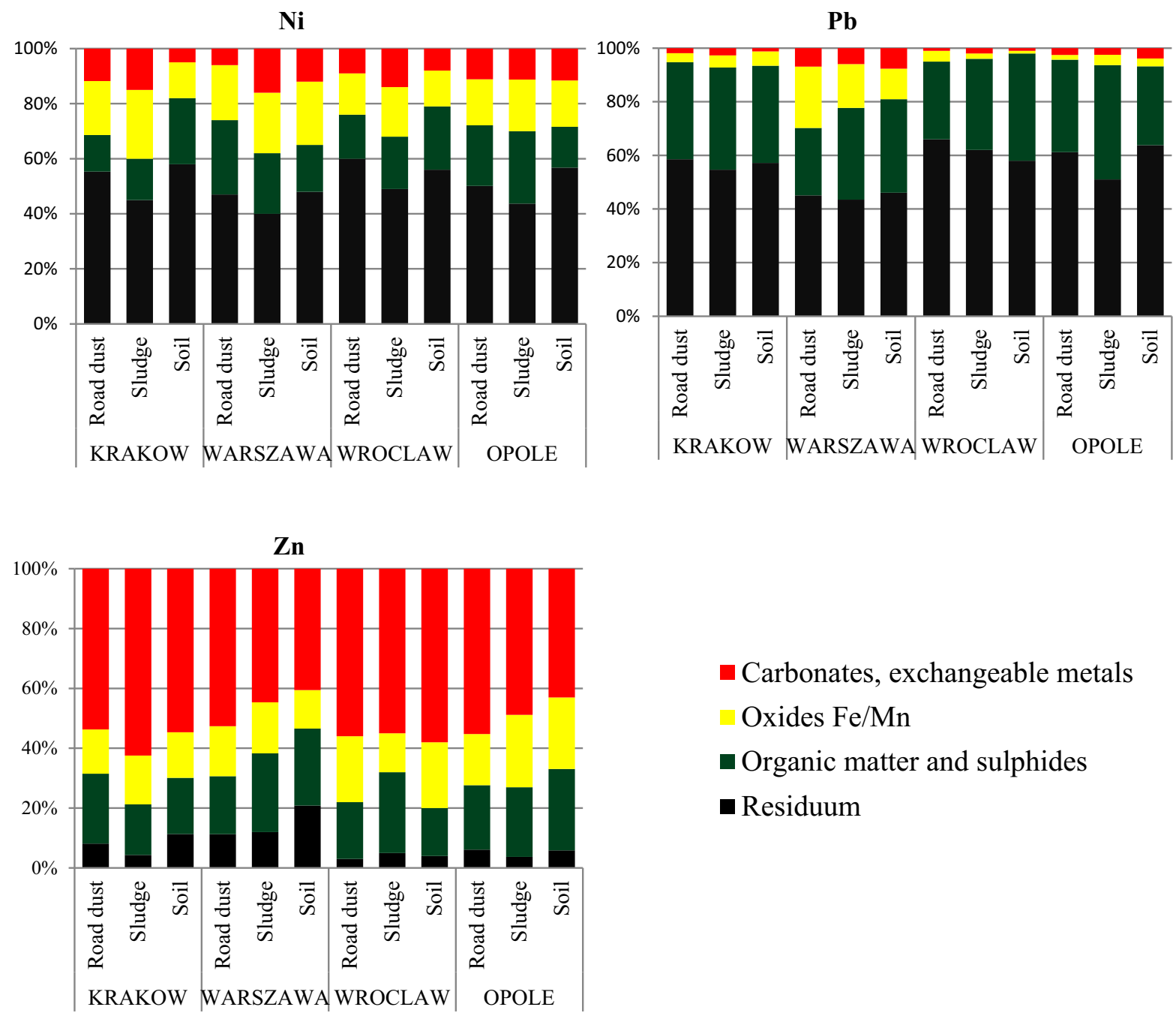

- Carbonates, exchangeable metals

Oxides Fe/Mn

- Organic matter and sulphides

- Residuum

Fig. 2 Chemical fractionation of $\mathrm{Cd}, \mathrm{Cu}, \mathrm{Ni}, \mathrm{Pb}$ and $\mathrm{Zn}$ in grain size $<20 \mu \mathrm{m}$ of road environment samples 
Table 6 I geo index in the fraction $<20 \mu \mathrm{m}$ of road environment samples

\begin{tabular}{|l|c|c|c|c|c|}
\hline Elements/I-geo & $\mathrm{Cd}$ & $\mathrm{Cu}$ & $\mathrm{Pb}$ & $\mathrm{Ni}$ & $\mathrm{Zn}$ \\
\hline & \multicolumn{5}{|c|}{ Kraków } \\
\hline Road dust & 2 & 3 & 3 & 0 & 3 \\
\hline Sludge & 3 & 2 & 3 & 0 & 3 \\
\hline Topsoil & 3 & 1 & 3 & 0 & 3 \\
\hline & \multicolumn{5}{|c|}{ Warszawa } \\
\hline Road dust & 1 & 3 & 3 & 0 & 3 \\
\hline Sludge & 3 & 3 & 3 & 0 & 4 \\
\hline Topsoil & 1 & 2 & 3 & 0 & 2 \\
\hline & \multicolumn{5}{|c|}{ Wrocław } \\
\hline Road dust & 2 & 1 & 2 & 0 & 3 \\
\hline Sludge & 2 & 2 & 3 & 0 & 3 \\
\hline Topsoil & 2 & 0 & 2 & 0 & 2 \\
\hline & 1 & 2 & 1 & 1 & 2 \\
\hline Road dust & 2 & 2 & 2 & 1 & 3 \\
\hline Sludge & 2 & 0 & 1 & 1 & 2 \\
\hline Topsoil & \multicolumn{5}{|l|}{ Opole } \\
\hline
\end{tabular}

\begin{tabular}{|c|c|}
\hline I-geo $\leq 0$ & 0 \\
\hline $0<$ I-geo $\leq 1$ & 1 \\
\hline $1<$ I-geo $\leq 2$ & 2 \\
\hline $2<$ I-geo $\leq 3$ & 3 \\
\hline $3<$ I-geo $\leq 4$ & 4 \\
\hline
\end{tabular}

Unpolluted

Unpolluted to moderately polluted

Moderately polluted

Moderately to strongly polluted

Strongly polluted

from storm drains and road dust also in Krakow and Wroclaw. Statistical parameters of the examined road environment samples are depicted in Table 4.

Concentration of metals in the studied road dust was then used to calculate I geo accumulation index according to Müller (1969), and the results are depicted in Table 5. Based on I geo classification, it can be concluded that in Krakow, Warszawa and Wroclaw, due to heavy congested traffic, all types of road environment samples, i.e. road dust, sludge from storm drains and surrounding soil, have been classified mainly as class 3 (moderately to strongly polluted) and class 4 (strongly polluted) with respect to sludge from
Warszawa. No elevated concentration of $\mathrm{Ni}$ was found in any of the road environment samples.

Fractionation studies are conducted on the selected samples and depicted in Fig. 2. Table 6 reveals that $\mathrm{Zn}$ was the most mobile and bioavailable of all investigated metals; on average, $41-62 \%$ of $\mathrm{Zn}$ was bound with carbonates and/or exchangeable metal fractions. This heavy metal was also the most abundant in road environment sediment and sludge and came mostly from tire wear. Its high concentrations resulted from the addition of $\mathrm{ZnO}$ and $\mathrm{ZnS}$ to the tire during vulcanization. $\mathrm{Zn}$ and $\mathrm{ZnO}$ were associated mainly with carbonates and exchangeable fractions; on 
average, 54\% of $\mathrm{Zn}$ was found in road dust, $53 \%$ in sludge and $49 \%$ in the surrounding soil. Moreover, $\mathrm{ZnS}$ and $\mathrm{Zn}^{2+}$ are adsorbed on Fe(III) hydroxides on average $18 \%$ (in dust and sludge) and $19 \%$ in soil. The results are in line with the findings of Swietlik et al. 2015, who estimated that $54 \%$ of $\mathrm{Zn}$ in road dust collected from Falencice and Jedlińsk E77 expressway near Warszawa, Poland, was predominantly bound with weak acid fraction. Additionally, high mobility was found for Cd, associated significantly (25-42\%) with easily leachable carbonates and exchangeable fractions. This specific metal can cause extreme threat to the environment, especially in Warszawa, where its concentration was found to be as high as $6.42 \mathrm{mg} / \mathrm{kg}$ in sludge from storm drains, exceeding the background levels 21 times.

No significant environmental risk was associated with $\mathrm{Ni}$ or $\mathrm{Cu}$; these metals, however, when ingested can be extremely toxic and even lethal. As estimated by Zhou et al. (2015), exposure dose of $\mathrm{Pb}, \mathrm{Cd}, \mathrm{Cu}$ sourced from road dust by ingestion is two orders of magnitude higher than the corresponding dermal dose and up to four orders of magnitude higher than the inhalation exposure. Copper in all samples is bound in $34.6-54.3 \%$ with organic matter and sulphites but also with the residuum (30-52\%). Total concentration of $\mathrm{Ni}$ is rather low in all road environment samples; approximately $90 \%$ is bound with stable fractions.

Table 7 Mobility and bioavailability of metals in the fractions

\begin{tabular}{ll}
\hline $\begin{array}{l}\text { Road dust } \\
\text { Carbonates, exchangeable } \\
\text { metals }\end{array}$ & $\mathrm{Zn}>\mathrm{Cd}>\mathrm{Cu} \approx \mathrm{Ni}>\mathrm{Pb}$ \\
$\begin{array}{l}\text { Oxides Fe/Mn } \\
\text { Organic matter and sulphides }\end{array}$ & $\mathrm{Cd}>\mathrm{Cn} \approx \mathrm{Ni}>\mathrm{Pb}>\mathrm{Cu}>\mathrm{Ni}>\mathrm{Cd}$ \\
$\begin{array}{l}\text { Residual } \\
\text { Sludge }\end{array}$ & $\mathrm{Pb}>\mathrm{Ni}>\mathrm{Cu}>\mathrm{Cd}>\mathrm{Zn}$ \\
$\begin{array}{l}\text { Carbonates, exchangeable } \\
\text { metals }\end{array}$ & $\mathrm{Zn}>\mathrm{Cd}>\mathrm{Ni}>\mathrm{Cu}>\mathrm{Pb}$ \\
$\begin{array}{l}\text { Oxides Fe/Mn } \\
\text { Organic matter and sulphides }\end{array}$ & $\mathrm{Cd}>\mathrm{Cu}>\mathrm{Zn}>\mathrm{Pb}>\mathrm{Cu}>\mathrm{Ni}>\mathrm{Cd}$ \\
$\begin{array}{l}\text { Residual } \\
\text { Soil }\end{array}$ & $\mathrm{Pb}>\mathrm{Ni}>\mathrm{Cu}>\mathrm{Cd}>\mathrm{Zn}$ \\
Carbonates, exchangeable & $\mathrm{Zn}>\mathrm{Cd}>\mathrm{Ni}>\mathrm{Cu}>\mathrm{Pb}$ \\
$\quad$ metals & $\mathrm{Cd}>\mathrm{Zn}>\mathrm{Ni}>\mathrm{Pb}>\mathrm{Cu}$ \\
Oxides Fe/Mn & $\mathrm{Cu}>\mathrm{Pb}>\mathrm{Zn}>\mathrm{Ni}>\mathrm{Cd}$ \\
Organic matter and sulphides & $\mathrm{Pb}>\mathrm{Ni}>\mathrm{Cu}>\mathrm{Zn}>\mathrm{Cd}$ \\
Residual & \\
\hline
\end{tabular}

Total concentration of lead is rather high in all examined samples, since this element is an important component of bearing alloys and was used commonly as a material for wheel balancing weight now replaced by zinc weights. Additionally, it should be noted that $\mathrm{Pb}$ is a very persistent element. Its elevated concentrations in urban dust could be a consequence of common use of $\mathrm{PbO}_{4}$ as a gasoline additive in Poland up to March 2005. Despite high lead concentrations, most of $\mathrm{Pb}$ is in bound with stable fractions and only negligible percentage is mobile. In the road environment samples derived from Krakow, Wroclaw and Opole lead is bound approximately 1-2\% with carbonates and exchangeable fractions and up to $7.6 \%$ in soil in Warszawa.

\section{Conclusion}

The finest fractions of road dust, mixed sludge and sediment from storm drains as well as soil from the vicinity of roads (up to $<20 \mu \mathrm{m}$ ) were significantly contaminated with all of the investigated metals, in particular with $\mathrm{Zn}, \mathrm{Cu}, \mathrm{Pb}$ and $\mathrm{Cd}$. Since copper and zinc are well-recognized key tracers of non-exhaust emission, their high concentrations confirm that brake and tire wear highly contributes to road environmental samples contamination with heavy metals. More specifically, it can be concluded that sludge and sediments from storm drains are slightly more contaminated than road dust and soil. Fractionation study revealed that mobility of the examined metals decreases in the following order: $\mathrm{Zn}(43-62 \%)>\mathrm{Cd}$ $(25-42 \%)>\mathrm{Ni} \quad(6-16 \%)>\mathrm{Cu} \quad(3-14 \%)>\mathrm{Pb}$ (1-8\%) (Table 7). It should be noted, however, that metals (even if not mobile in the environment) can cause serious health concerns when ingested or inhaled. Therefore, metals in road environment samples should also be regarded as a secondary pollution source. Extremely high concentrations of metals in sludge from storm drains in Krakow and Warszawa could potentially pollute the Vistula River, which enters the Baltic Sea, while in Wroclaw and Opole traffic-related metals could enter the Oder River on the border with Germany.

Acknowledgements The research leading to these results has received funding from the Polish-Norwegian Research Programme operated by the National Centre for Research and 
Development under the Norwegian Financial Mechanism 2009-2014 in the frame of Project Contract No. Pol-Nor/ 208849/106/2015.

Open Access This article is distributed under the terms of the Creative Commons Attribution 4.0 International License (http:// creativecommons.org/licenses/by/4.0/), which permits unrestricted use, distribution, and reproduction in any medium, provided you give appropriate credit to the original author(s) and the source, provide a link to the Creative Commons license, and indicate if changes were made.

\section{References}

Abu-Allaban, M., Gillies, J. A., Gertler, A. W., Clayton, R., \& Proffitt, D. (2003). Tailpipe, resuspended road dust, and brake-wear emission factors from on-road vehicles. Atmospheric Environment, 37(37), 5283-5293.

Adamiec, E., Jarosz-Krzemińska, E., \& Wieszała, R. (2016). Heavy metals from non-exhaust vehicle emissions in urban and motorway road dusts. Environmental Monitoring and Assessment, 188, 369.

Aphekom. (2011). Improving knowledge and communication for decision making on air pollution and health in Europe. Summary report of the Aphekom project 2008-2011, http:// www.endseurope.com/docs/110302b.pdf Accessed 10 December 2016.

Bukowiecki, N., Lienemann, P., Hill, M., Figi, R., Richard, A., Furger, M., et al. (2009). Real-world emission factors for antimony and other brake wear related trace elements: size segregated values for light and heavy duty vehicles. Environmental Science and Technology, 43, 8072-8078.

Bukowiecki, N., Lienemann, P., Hill, M., Furger, M., Richard, A., Amato, F., et al. (2010). PM10 emission factors for nonexhaust particles generated by road traffic in an urban street canyon and along a freeway in Switzerland. Atmospheric Environment, 44(19), 2330-2340.

Carrero, J. A., Arrizabalaga, I., Bustamante, J., Goienaga, N., Arana, G., \& Madariaga, J. M. (2013). Diagnosing the traffic impact on roadside soils through a multianalytical data analysis of the concentration profiles of traffic-related elements. Science of the Total Environment, 458-460, 427-434.

Chan, D., \& Stachowiak, G. W. (2004). Review of automotive brake friction materials. Proceedings of the Institution of Mechanical Engineers, Part D: Journal of Automobile Engineering, 218(9), 953-966.

Chen, T. B., Zheng, Y. M., Lei, M., Huang, Z. C., Wu, H. T., Chen, H., et al. (2005). Assessment of heavy metal pollution in surface soils of urban parks in Beijing, China. Chemosphere, 60(4), 542-551.

Dahl, A., Gharibi, A., Świetlicki, E., Gudmundsson, A., Bohgard, M., Ljungman, A., et al. (2006). Traffic-generated emissions of ultrafine particles from pavement e tire interface. Atmospheric Environment, 40(7), 1314-1323.

EPA (1996). Method 3050B: Acid digestion of sediments, sludges, and soils. Revision 2.
EPA (1998). Method 6020B: Inductively coupled plasma-mass spectrometry. Revision 2.

Eriksson, M., Bergman, F., \& Jacobson, S. (1999). Surface characterisation of brake pads after running under silent and squealing conditions. Wear, 232, 163-167.

Eriksson, M., \& Jacobson, S. (2000). Tribological surfaces of organic brake pads. Tribology International, 33(12), 817-827.

European Environment Agency (EEA). (2014). Air quality in Europe. http://www.eea.europa.eu/publications/air-qualityin-europe-2014. Accessed 23 December 2016.

European Environment Agency (EEA). (2016). Air quality in Europe. http://www.eea.europa.eu/publications/air-qualityin-europe-2016. Accessed 23 December 2016.

Filgueiras, A. F., Lavilla, I., \& Bendicho, C. (2002). Chemical sequential extraction for metal partitioning in environmental solid samples. Environmental Monitoring, 4, 823-857.

Garg, B. D., Cadle, S. H., Mulawa, P. A., \& Groblicki, P. J. (2000). Brake wear particulate matter emissions. Environmental Science and Technology, 34, 4463-4469.

Gasser, M., Riediker, M., Mueller, L., Perrenoud, A., Blank, F., Gehr, P., et al. (2009). Toxic effects of brake wear particles on epithelial lung cells in vitro. Particle and Fibre Toxicology, 6, 30.

Gehrig, R., Hill, M., Buchmann, B., Imhof, D., Weingartner, E., \& Baltensperger, U. (2004). Separate determination of PM10 emission factors of road traffic for tailpipe emissions and emissions from abrasion and resuspension processes. International Journal of Environmental Pollution, 22, 312-325.

Gottipolu, R. R., Landa, E. R., Schladweiler, M. C., McGee, J. K., Ledbetter, A. D., Richards, J. H., et al. (2008). Cardiopulmonary responses of intratracheally instilled tire particles and constituent metal components. Inhalation Toxicology, 20(5), 473-484.

Grigoratos, T., \& Martini, G. (2015). Brake wear particle emissions: a review. Environmental Science and Pollution Research, 22, 2491-2504.

Gudmand-Hoyer, A., Bach, A., Neilsen, G. T., \& Per, M. (1999). Tribiological properties of automotive disc brakes with solids lubricants. Wear, 232, 168-175.

Harrison, R. M., Jones, A. M., Gietl, J., Yin, J., \& Green, D. C. (2012) Estimation of the contributions of brake dust, tire wear, and resuspension to nonexhaust traffic particles derived from atmospheric measurements. Environmental Science and Technology, 46(12), 6523-6529. doi:10.1021/ es300894r.

Kam, W., Liacos, J. W., Schauer, J. J., Delfino, R. J., \& Sioutas, C. (2012). Size-segregated composition of particulate matter (PM) in major roadways and surface streets. Atmospheric Environment, 55, 90-97.

Kennedy, N. J., \& Hinds, W. C. (2002). Inhalability of large solid particles. Journal of Aerosol Science, 33, 237-255.

Kukutschová, J., Moravec, P., Tomášek, V., Matějka, V., Smolík, J., Schwarz, J., et al. (2011). On airborne nano/ micro-sized wear particles released from low-metallic automotive brakes. Environmental Pollution, 159(4), 998-1006.

Kumar, P., Pirjola, L., Ketzel, M., \& Harrison, R. M. (2013). Nanoparticle emissions from 11 non-vehicle exhaust 
sources-A review. Atmospheric Environment, 67, 252-277.

Lawrence, S., Sokhi, R., Ravindra, K., Mao, H., Prain, H., D., \& Bull, I. D. (2013). Source apportionment of traffic emissions of particulate matter using tunnel measurements. Atmospheric Environment, 77, 548-557.

Mantecca, P., Sancini, G., Moschini, E., Farina, F., Gualtieri, M., Rohr, A., et al. (2009). Lung toxicity induced by intratracheal instillation of size-fractionated tire particles. Toxicology Letters, 189(3), 206-214.

Mathissen, M., Scheer, V., Vogt, R., \& Benter, T. (2011). Investigation on the potential generation of ultrafine particles from the tire e road interface. Atmospheric Environment, 45, 6172-6179.

Mossop, K. F., \& Davidson, C. M. (2003). Comparison of original and modified BCR sequential extraction procedures for fractionation of cooper, iron, lead, manganese and zinc in soils and sediments. Analytic Chimica Acta, 478, 111-118.

Müller, G. (1969). Index of geoaccumulation in sediments of the Rhine River. Geology Journal, 2, 109-118.

Pant, P., \& Harrison, R. M. (2013). Estimation of the contribution of road traffic emissions to particulate matter concentrations from field measurements: A review. Atmospheric Environment, 77, 78-97.

Pratt, C., \& Lottermoser, B. G. (2007). Mobilisation of trafficderived trace metals from road corridors into coastal stream and estuarine sediments, Cairns, northern Australia. Environmental Geology, 52, 437-448.

Radziemska, M., \& Fronczyk, J. (2015). Level and contamination assessment of soil along an expressway in an ecologically valuable area, Central Poland. International Journal of Environmental Research and Public Health, 12(10), 13372-13387.

Rexeis, M., \& Hausberger, S. (2009). Trend of vehicle emission levels until 2020-Prognosis based on current vehicle measurements and future emission legislation. Atmospheric Environment, 43, 4689-4698.

Riediker, M., Cascio, W. E., Griggs, T. R., Herbst, M. C., Bromberg, P. A., Neas, L., et al. (2004a). Particulate matter exposure in cars is associated with cardiovascular effects in healthy, young men. American Journal of Respiratory and Critical Care Medicine, 169, 934-940.

Riediker, M., Devlin, R. B., Griggs, T. R., Herbst, M. C., Bromberg, P. A., Williams, R. W., et al. (2004b). Cardiovascular effects in patrol officers are associated with fine particulate matter from brake wear and engine emissions. Particle and Fibre Toxicology, 1, 2.
Świetlik, R., Trojanowska, M., Strzelecka, M., \& BochoJaniszewska, A. (2015). Fractionation and mobility of $\mathrm{Cu}$, $\mathrm{Fe}, \mathrm{Mn}, \mathrm{Pb}$ and $\mathrm{Zn}$ in the road dust retained on noise barriers along expressway e A potential tool for determining the effects of driving conditions on speciation of emitted particulate metals. Environmental Pollution, 196(2015), 404-413.

Tervahattu, H., Kupiainen, K. J., Raisanen, M., Makela, T., \& Hillamo, R. (2006). Generation of urban road dust from anti-skid and asphalt concrete aggregates. Journal of Hazardous Materials, 132, 39-46.

Thorpe, A., \& Harrison, R. M. (2008). Sources and properties of non-exhaust particulate matter from road traffic: A review. Science of the Total Environment, 400, 270-282.

Thorpe, A. J., Harrison, R. M., Boulter, P. G., \& Mc Crae, I. S. (2007). Estimation of particle resuspension source strength on a major London Road. Atmospheric Environment, 41, 8007-8020.

Turekian, K. K., \& Wedephol, H. H. (1961). Distribution of the elements in some major units of the Earth's crust. Geological Society of America Bulletin, 72, 175-192.

Ure, A. M., Quevauviller, P., Muntau, H., \& Griepink, B. (1993). Speciation of heavy metals in soils and sediments. An account of the improvement and harmonization of extraction techniques undertaken under auspices of the BCR of the Commission of the European Communities. International Journal of Environmental Analytical Chemistry, 51, 135-151.

van der Gon, H. A., Gerlofs-Nijland, M. E., Gehrig, R., Gustafsson, M., Janssen, N., Harrison, R. M., et al. (2013). The policy relevance of wear emissions from road transport, now and in the future-An international workshop report and consensus statement. Journal of the Air and Waste Management Association, 63(2), 136-149.

Werkenthin, M., Kluge, B., \& Wessolek, G. (2014). Metals in European roadside soils and soil solution-A review. Environmental Pollution, 189, 98-110.

World Health Organisation (WHO) Regional Office for Europe. (2013). Health effects of particulate matter: Policy implications for countries in Eastern Europe, Caucasus and central Asia. http://www.euro.who.int/_data/assets/pdf_ file/0006/189051/Health-effects-of-particulate-matter-final -Eng.pdf. Accessed 23 December 2016.

Zhou, Q., Zheng, N., Liu, J., Wang, Y., Sun, Ch., Liu, Q., et al. (2015). Residents health risk of $\mathrm{Pb}, \mathrm{Cd}$ and $\mathrm{Cu}$ exposure to street dust based on different particle sizes around zinc smelting plant Northeast of China. Environmental Geochemistry and Health, 37, 207-220. 